\title{
Editorial:
}

\section{Prosperity and Poverty in Times of Crisis}

\author{
Steven Shardlow, Professor, Salford University, UK
}

At the time of writing this editorial, the global financial system has been in a state of turmoil for several weeks. Banks refuse to lend to each other, governments across the world have been compelled to prop up their failing banking systems I using an unprecedented provision of public monies for what was a private system at the very heart of the capitalist project. What of the causes of this financial 'train wreck'... those lie deep within the motivation and drivers that impel the banking system to create profit. So the paradox, systems and structures that have for many parts of the economically developed world brought prosperity now are the harbingers of gloom as disaster. The effects on the so called 'real economy' are only just starting to be felt. Most economists have predicted recession with increasing numbers of company failures, increasing unemployment and increasing commodity prices. The impact on populations around the world will be profound and the impact on the poorest can be expected to be disproportionally large. Some economists have suggested that these effects could last for several years. So social workers can anticipate a significant increase in the range and depth of social problems associated wit poverty and unemployment over the next few years. Social work will be part of the process of clearing up the human cost and misery caused by the banking crisis.

The first article in this edition, by Pamela Brown, is about poverty a comparison of poverty in different states; Norway, Russia and the United States. The particular focus is mothers who are living on public assistance. Despite the different cultural contexts, many similarities are identified in the experiences of both social workers and mothers in respect of poverty. The second article by Siv Oltedal explores the nature of interactions between social workers and clients in social welfare offices in Norway. Here the potential for miscommunication is enormous especially when the client is under stress, as many will be when seeking assistance - many of whom will be living in poverty.

Such themes, concerning how to work with people, are further dev eloped in a translation of a book chapter by Torill Jensen. In this she develops a discussion of who to work with people from different cultural backgrounds.

Social work as a professional discipline often does not seem embedded in its own history. 'Now 'is so often the focus for social work. The article by Victoria Tevlina is extremely welcome in that it comments on the historical development of welfare systems in Norway and Russia from the nineteenth century, In this edition of the journal we are pleased to carry an account of from a student social worker of how she responded to a client with HIV/Aids in Uganda. Lack of resources, and poverty are also themes that ruin through this discussion. 
Social workers confront poverty on a regular basis; it is embedded in their work. It should not be something that we accept - it must always be something that we seek to challenge and eradicate. 